\title{
Indirect effects of overfishing on Caribbean reefs: Sponges overgrow reef-building corals
}

Tse-Lynn Loh, Steven E McMurray, Timothy P Henkel, Jan Vicente, Joseph Pawlik

Consumer-mediated indirect effects at the community-level are difficult to demonstrate empirically. Here, we show an explicit indirect effect of overfishing on competition between sponges and reef-building corals from surveys of 69 sites across the Caribbean. Leveraging the large-scale, long-term removal of sponge predators, we selected overfished sites where intensive methods, primarily fish-trapping, have been employed for decades or more, and compared them to sites in remote or marine protected areas (MPAs) with variable levels of enforcement. Sponge-eating fishes (primarily angelfishes and parrotfishes) were counted at each site, and the benthos surveyed, with coral colonies scored for interaction with sponges. Overfished sites had $>3$ fold more overgrowth of corals by sponges, and mean coral contact with sponges was $25.6 \%$, compared with $12.0 \%$ at less-fished sites. Greater contact with corals by sponges at overfished sites was mostly by sponge species palatable to sponge predators. Palatable species have faster rates of growth or reproduction than defended sponge species, which instead make metabolically expensive chemical defenses. These results validate the top-down conceptual model of sponge community ecology for Caribbean reefs, as well as provide an unambiguous justification for MPAs to protect threatened reef-building corals.

An unanticipated outcome of the benthic survey component of this study was that overfished sites had lower mean macroalgal cover (23.1\% vs. $38.1 \%)$, a result that is contrary to prevailing assumptions about seaweed control by herbivorous fishes. Because we did not quantify herbivores for this study, we interpret this result with caution, but suggest that additional large-scale studies comparing intensively overfished and MPA sites are warranted to examine the relative impacts of herbivorous fishes and urchins on Caribbean reefs. 
2 REVISED MS. - 30 March 2015

\section{Authors:}

Tse-Lynn Loh ${ }^{1 \dagger}$, Steven E. McMurray ${ }^{1}$, Timothy P. Henkel ${ }^{2}$, Jan Vicente ${ }^{3}$ \& Joseph R. Pawlik ${ }^{1 *}$

5

6

${ }^{1}$ Department of Biology and Marine Biology and Center for Marine Science, University of North Carolina Wilmington, Wilmington, NC 28409, USA.

${ }^{2}$ Valdosta State University, Department of Biology, 1500 N Patterson St, Valdosta, Georgia 31698, USA.

${ }^{3}$ Institute of Marine and Environmental Technology, University of Maryland Center for Environmental Science, 701 E Pratt St. Suite 236, Baltimore, MD 21202, USA.

$\dagger$ Present address: Daniel P. Haerther Center for Conservation and Research, John G. Shedd Aquarium, Chicago, IL 60605, USA.

$17{ }^{*}$ Correspondence to Joseph Pawlik, Center for Marine Science, University of North Carolina

18 Wilmington, 5600 Marvin K Moss Lane, Wilmington NC 28409. Tel: 910-9622377, Fax: 910-9622410

19 pawlikj@uncw.edu 


\section{Introduction}

Food web dynamics are considered fundamental to the study of ecology (Fretwell, 1987), and are the subject of considerable research despite the theoretical limitations brought by the complexity of natural ecosystems. Policy decisions relevant to the management of living natural resources require an in-depth understanding of ecosystem structure and properties (Hooper et al., 2005; Farber et al., 2006). Among the mechanisms important to ecosystem function are indirect effects, which alter community structure through predation (e.g., trophic cascade) or competition (e.g., indirect mutualism; Wootton, 1994). Indirect effects can be difficult to identify or quantify, particularly for complex ecosystems with demonstrable bottom-up control (Strong, 1992). While a number of examples of indirect effects have been found among both terrestrial and aquatic ecosystems, with the rocky intertidal presenting a particularly well-studied example (Menge, 1995), most of these have been described at the specieslevel rather than at the community-level (Polis et al., 2000).

Caribbean coral reefs are strikingly different from those of the Indo-Pacific in having two- to ten-fold greater biomass of sponges (Wilkinson \& Cheshire, 1990). Sponges have been ignored in broader discussions of coral reef community ecology, in part because they were considered to be free of top-down control (Randall \& Hartman, 1968). However, a survey of sponge chemical defenses against fish predators revealed that both palatable and defended sponge species were found on reefs (Pawlik et al., 1995). Manipulative field experiments demonstrated that palatable species had faster rates of wound healing, tissue growth, and recruitment that act in opposition to grazing by spongeeating fishes (primarily angelfishes and parrotfishes), while defended species produced defensive secondary metabolites (e.g., Walters \& Pawlik, 2005; Pawlik et al. 2008; Leong \& Pawlik, 2010). In light of these resource trade-offs, a conceptual model of sponge ecology was proposed that included three trophic levels and indirect effects of sponge competition with reef-building corals (Pawlik, 2011). 
43 The consumptive indirect effects of this conceptual model were tested by surveying sites on opposite

ends of a spectrum of human fishing intensity on Caribbean reefs (Loh \& Pawlik, 2014), where a fortuitous long-term manipulative experiment has been ongoing for decades or longer, with some reefs heavily overfished through the use of non-selective fish-traps and nets (e.g., Jamaica, Martinique, Panama), while others have been relatively protected from fishing, either because of low human population density or through the imposition of marine protected areas (MPAs; Bonaire, Cayman Islands, Southeastern Bahamas Islands). This test of theory was noteworthy not only for its spatial scale, but also because it examined community-level differences in chemical defenses of a taxonomically diverse group across a large geographic region, with identification of the palatability of 109 sponge species. Results of the Caribbean-wide survey showed that, at less-fished reef sites with many sponge predators, there was a high abundance of chemically defended sponge species, while overfished sites were dominated by palatable species that have faster rates of growth, reproduction or recruitment (Loh \& Pawlik, 2014).

In the present study, we used benthic surveys that were performed contemporaneously with the fish and sponge surveys of the previous study (Loh \& Pawlik, 2014) to test the indirect effects of overfishing on competition between sponges and reef-building corals. We predicted that removing the top-down control of sponges by overfishing sponge predators would increase competitive sponge-coral interactions, because faster-growing palatable sponges would dominate in the absence of sponge predators. Our surveys also recorded the abundance of other benthic organisms, including macroalgae, at 69 sites across the Caribbean, providing a snapshot of reef community structure and allowing for comparisons of the relative abundances of competitive benthic groups for sites at the extremes of fishing intensity.

\section{Materials and Methods}


To maximize the manipulative effect of fishing pressure, we chose survey sites at the extremes of a gradient of fishing intensity, focusing on overfished sites where fish-traps and nets have been used for decades, and less-fished sites that were either far from anthropogenic impacts, or had been maintained as MPAs. Descriptions and a map of sites have been previously published (Loh \& Pawlik, 2014). Surveys of coral reefs were carried out at 69 sites from 12 countries in the Tropical Northwestern Atlantic marine province ("Caribbean") at depths of 10-20 m, except for six sites in Panama and two sites off Florida, USA that were surveyed at 2-7 m (Loh \& Pawlik, 2014). Countries surveyed were the Bahamas Islands, Panama, Bonaire, Curaçao, USA (Florida Keys and Puerto Rico), Martinique, St. Eustatius, St. Lucia, the Dominican Republic, Jamaica, Cayman Islands and Mexico (Yucatan coast). Reef site selection was based on previously published assessments of fishing pressure (Burke \& Maidens, 2004), prior to our own surveys of the abundance of sponge-eating fishes and the presence of fish-traps.

At each survey site, spongivorous fishes (all angelfishes and the three dominant parrotfish species in the genus Sparisoma) were counted using the Reef Check Survey Methodology (http://www.reefcheck.org) in a volume $2.5 \mathrm{~m}$ on each side of, and $5 \mathrm{~m}$ above, four end-to-end $20 \mathrm{~m}$ transect lines placed along the same depth profile (total volume above the reef $=2000 \mathrm{~m}^{3}$ ). The Spongivore Index (SI) was calculated to correct for differences in the grazing activity of small fishes at overfished sites. For sites where (1) fish were observed to be very small $(<10 \mathrm{~cm})$, and (2) nets or fishtraps were observed, the SI was calculated by dividing the total fish abundance by 10 ; for all other sites, the SI was equal to the total number of fish counted (Loh \& Pawlik, 2014). We consider the SI to be a highly conservative measure of fish grazing activities, because literature-based grazing estimates have compared the impact of one large parrotfish ( $>25 \mathrm{~cm}$ TL) to 24 small $(5-10 \mathrm{~cm}$ TL) parrotfishes 
88 (Fox \& Bellwood, 2007), and one large $(35 \mathrm{~cm})$ to 75 small $(15 \mathrm{~cm})$ parrotfishes (Lokrantz et al., 89 2008).

At the same sites where fish abundance was counted, benthic community surveys were carried out by evenly placing a $1 \times 1 \mathrm{~m}^{2}$ quadrat 5 times along each $20 \mathrm{~m}$ transect line, with 5 replicate transect lines laid end-to-end at similar depth, and a gap of $5 \mathrm{~m}$ between each transect (total of 25 quadrats per survey site). The benthos under 25 points within each quadrat were classified into the following categories: reef-building coral, sponge, fire coral (Millepora sp. C Linnaeus, 1758), gorgonian, zoanthid, other benthos, bare rock or dead coral, rubble, sand, silt, macroalgae (all erect species, but primarily Dictyota JV Lamouroux, 1809; Halimeda JV Lamouroux, 1812; Lobophora J Agardh, 1894; and Microdictyon spp. Decaisne, 1841), turfs (including cyanobacterial mats), and coralline algae. A total of 625 points were recorded at each survey site (Supplemental Information Table S1). Coralsponge interactions were quantified within the same number of quadrats along the same transect lines. For all coral colonies with at least $50 \%$ of their surface areas within each quadrat, we counted coral colonies in 3 categories: (1) those having no contact with sponges, (2) those that were growing adjacent to and in contact with sponges, and (3) those that were overgrown by sponges such that sponge tissue was covering live coral tissue.

The percentage of coral colonies having no contact with sponges, growing adjacent to sponges, and overgrown by sponges at each site were plotted in a non-metric multi-dimensional scaling (nMDS) ordination with Bray-Curtis distances, followed by ANOSIM (analysis of similarity) to compare coralsponge interactions (Clarke, 1993). Benthic occurrence data (number per 625 points per transect site) were square-root transformed for an nMDS ordination, and individual variables were then correlated with the scores of axes 1 and 2. ANOSIM was used to compare benthic occurrences between overfished and less-fished sites, with SIMPER (percentage similarity) to determine which benthic categories contributed most to group differences (Clarke, 1993). Additionally, we performed linear 
112 regressions to examine the effect of SI on cover of palatable sponges, the percentage of coral

113 overgrown by sponges and macroalgal cover, and to relate cover of palatable sponges with coral 114 overgrowth. All analyses were carried out in R v2.15.2 and PRIMER v6.

\section{Results}

The mean Spongivore Index (SI) for less-fished sites was $42.5 \pm 2.8$ (SE) within the survey volume of $2000 \mathrm{~m}^{3}$ ( $\mathrm{n}=44$ sites), while overfished sites had a mean SI of $2.1 \pm 0.3$ per $2000 \mathrm{~m}^{3}(\mathrm{n}=25$ sites). Coral colonies on reefs that were less impacted by fishing ( $n=22,827$ colonies, 44 sites) had less interaction with sponges, with $12.0 \%$ of colonies growing either adjacent to sponges $(8.8 \pm 0.9 \%)$ or overgrown by sponges $(3.2 \pm 0.5 \%)$. The incidence of coral-sponge interactions was more than double on overfished reefs ( $\mathrm{n}=11,278$ colonies, 25 sites), with $25.6 \%$ of corals growing next to sponges (14.9 $\pm 1.5 \%)$ or overgrown by sponges $(10.7 \pm 2.9 \%)$ (Figs. 1,2$)$. Accordingly, in an non-metric multidimensional scaling (nMDS) plot of sponge-coral interactions, survey sites assembled into two groups (stress $=0.02$, Fig. 3): (1) sites with higher proportions of coral-sponge interactions and lower spongivore abundance (e.g. Jamaica, Martinique, Panama); and (2) sites with corals that were less frequently in contact with sponges and higher spongivore abundance (e.g. Bonaire, Cayman Islands, Florida Keys). Analysis of similarity (ANOSIM) between overfished $(n=25)$ and less-fished $(n=44)$ reefs indicated that coral-sponge interactions and the density of sponge-eating fishes were significantly different at $\mathrm{p}=0.002$, with a Global $\mathrm{R}$ of 0.17 .

On less-fished reefs with high abundances of sponge-eating fishes, most of the sponges that overgrew corals were slow-growing, chemically defended species $(70.9 \%)$, reflecting their greater abundance on reefs where predation pressure is high (Loh \& Pawlik, 2014). The chemically defended

134 Aplysina cauliformis HJ Carter, 1882 (Fig. 1A), also the most common sponge on Caribbean reefs 
135 (Loh \& Pawlik, 2014), had the highest number of encounters with corals, accounting for $14.3 \%$ of

136

137

138

139

140 overgrowth interactions (Table 1). On overfished reefs, $43.2 \%$ of the sponges that overgrew corals were the faster-growing, palatable species (Loh \& Pawlik, 2014), with the palatable sponge Niphates erecta P Duchassaing \& G Michelotti, 1864 most frequently recorded overgrowing corals (9.7\%, Table 1). Sponges with unknown chemical defense strategies accounted for only $0.2 \%$ and $0.1 \%$ of sponges overgrowing corals on less-fished and overfished reefs, respectively.

Linear regression analysis of all sites confirmed that palatable sponge cover was negatively correlated with SI $\left(\mathrm{p}<0.001 ; \mathrm{r}^{2}=0.280 ;\right.$ Fig. $\left.4 \mathrm{~A}\right)$. Also, linear regression analysis indicated that a higher percentage of coral colonies were overgrown by sponges as the cover of palatable sponges increased $\left(\mathrm{p}<0.001, \mathrm{r}^{2}=0.551\right)$. Correspondingly, there was a significant negative relationship between the percentage of corals overgrown by sponges and $\mathrm{SI}\left(\mathrm{p}=0.010, \mathrm{r}^{2}=0.095\right.$, Fig 4B).

From our benthic surveys, macroalgae comprised the most abundant benthic organisms on Caribbean coral reefs, with an overall cover of $28.6 \%$. Sponges and reef-building corals were next with total cover of $15.9 \%$ and $16.2 \%$, respectively (composition of benthos by survey site listed in Table S1). Reef-building corals were more abundant on reefs off Bonaire, Curaçao, the Dominican Republic, and Panama, with cover ranging from $22.1-33.3 \%$ by location. At other locations, coral cover was less than $15 \%$. The highest cover of macroalgae by location was found on overfished reefs off Jamaica (15.4 - 68.0\%, mean $=50.4 \%)$. However, sites having abundant sponge-eating fishes, such as Mira Por Vos Cays (Bahamas, 50.6\%), Lac Cai (Bonaire, 36.2\%), Banco Chinchorro (Mexico, 14.2 - 54.9\%, mean $=39.3 \%$ ), the Cayman Islands (35.2 - 51.7\%, mean $=45.1 \%)$ and Desecheo Island (Puerto Rico, $50.2 \%)$, also had high macroalgal cover.

While all less-fished sites grouped together in the nMDS, several overfished sites had benthic communities similar to less-fished sites (stress=0.19, Supplemental Information Fig. S1). Sponge and 
158 zoanthid cover was inversely correlated with Axis $1(r=-0.86$ and -0.74 respectively), while

159

160

161

162

163

164

165

166

167

168

169

170

171

172

173

174

175

176

177

178

179

180

macroalgal cover was positively correlated with Axis $1(\mathrm{r}=0.80)$ (Table S2). For Axis 2, sites were sorted based on turf $(r=0.86)$ and rock cover $(r=-0.64)$. Based on correlations with the ordination axes, reef-building coral cover did not contribute to the overall variation in community composition among survey sites $(r=-0.16$ and 0.08 respectively). From the ANOSIM, the benthic communities at less-fished sites were significantly different from overfished sites at $\mathrm{p}=0.001$, with a Global $\mathrm{R}$ of 0.34 . Percentage similarity (SIMPER) analysis showed that less-fished sites were characterized by higher macroalgal, rock, reef-building coral and coralline algal cover, and less turf and sponge cover (Table 2). Linear regression analysis of all sites also indicated that SI was not correlated with macroalgal cover $\left(\mathrm{p}=0.528, \mathrm{r}^{2}=0.006\right.$; Fig. $\left.4 \mathrm{C}\right)$.

\section{Discussion}

\section{Sponge overgrowth of corals was greater on overfished reefs.}

From the standpoint of Caribbean coral reef conservation, our study provides compelling justification for fishing restrictions to protect sponge-eating fishes (angelfishes and parrotfishes) in order to decrease competitive interactions between reef-building corals and sponges. The three-fold difference in overgrowth of corals by sponges between less-fished and overfished sites was substantial, particularly when over $25 \%$ of coral colonies at overfished sites were in contact with, or overgrown by, sponges. In a previous study, we demonstrated that a palatable sponge species, Mycale laevis $\mathrm{HJ}$ Carter, 1882, was restricted to refuge habitats when sponge-eating fishes were abundant, but overgrew living coral tissue when sponge predators were absent or rare (Loh \& Pawlik, 2012) (Fig. 1B). Here, we were able to observe this phenomenon at the community-level and across an entire geographic region. The competitive superiority of sponges over reef-building corals has been well documented, and is likely due to a combination of shading, physical inhibition of water flow and gas exchange 
181 (smothering), and the use of allelopathic secondary metabolites to kill coral tissue (Porter \& Targett,

182

183

184

1988; Thacker et al., 1998; Aronson et al., 2002; Pawlik et al., 2007) (Fig. 1). Because allelopathic metabolites are present in the mucus or exudates of some sponge species, mere proximity to reefbuilding corals may be sufficient to negatively impact coral physiology and reproduction, making affected colonies more susceptible to bleaching or pathogenesis (Sullivan, Faulkner \& Webb, 1983). With the recent announcement that five species of Caribbean reef-building corals are proposed for listing as "threatened species" under the United States Endangered Species Act (NOAA, 2014), the results of this study should be useful in justifying regulations to protect sponge-eating fishes.

This study underscores the distinctive ecology of Caribbean coral reefs relative to those in other parts of the world, a concept that is not new (Wilkinson \& Cheshire, 1990; Roff \& Mumby, 2012), yet often unacknowledged in reviews of coral reef ecosystem function. Sponges dominate benthic communities on Caribbean coral reefs to a greater degree than elsewhere, but this fact is usually obscured by sampling methods. Coral reef ecologists conventionally survey 2-dimensional benthic cover because of the time constraints of scuba diving and the complexity of reef topography. While overall cover of sponges from our surveys was nearly the same as corals (15.9 vs $16.2 \%)$, and well behind macroalgae (28.6\%), both reef-building corals and macroalgae consist primarily of thin layers of tissue intended to catch light for photosynthesis. The filter-feeding sponges recorded in these surveys were mostly thick-bodied, and in many cases massive or upright branching species, so that the actual biomass of sponges on Caribbean reefs (from reef crest to deep mesophotic reefs and including reef interstices) is likely to be orders of magnitude greater than that of algae or corals. Sponge communities are structured by top-down processes, but may be a rare example of a system unaffected by bottom-up factors (Pawlik et al., 2013; 2015). The primary reason for this may be the nutritional reliance of Caribbean reef sponges on dissolved organic carbon (DOC), which frees sponges from 
204 food-limitation and provides a trophic "loop" that returns refractory DOC from the water column to the 205 benthos (de Goeij et al., 2013). A similar nutritional strategy does not appear to be available to sponges 206 on more oligotrophic Indo-Pacific coral reefs (Wilkinson \& Cheshire, 1990).

207

\section{Macroalgal cover on overfished and less-fished sites.}

An ancillary outcome of the benthic surveys conducted for this study was the surprising result that macroalgal cover was not lower on less-fished reefs. Linear regression revealed no relationship between SI and macroalgal abundance (Fig. 4C), and the SIMPER analysis indicated that overfished reefs had lower macroalgal cover (Table 2). When reef sites were split based on SI (as in Fig. 2) mean percentage cover of macroalgae was significantly higher on less-fished than overfished reefs ( $38.1 \mathrm{vs}$ $23.1 \%$; one-tailed $\mathrm{t}$-test on arc-sine transformed data, $\mathrm{p}=0.044)$. It is generally understood that a greater abundance of herbivorous fishes correlates with less macroalgal cover (e.g., Knowlton \& Jackson, 2008), and one wide-ranging survey of Caribbean reefs has supported this view (e.g., Newman et al., 2006). Considering the methods used in this study, how valid is this contrary outcome?

Unlike sponges, macroalgae may undergo seasonal changes, with low abundance in the winter (Lirman and Biber 2000). Of the 69 surveys performed for the present study (Dataset S1, Loh and Pawlik 2014), most were carried out during the summer and early fall (June-October) when macroalgal cover is high. Only 3 surveys were performed in the winter (Florida Keys sites F1-F3), but these had relatively high macroalgal cover for 2 of 3 sites $(33,6,22 \%)$. Hence, there was no evident bias in the seasonal timing of surveys that would explain the observed relationship between fish abundance and macroalgal cover.

Spongivorous fishes were surveyed for the present study, not herbivores. It could be argued that in the absence of a full accounting of herbivorous fish species, any relationship between fish abundance and macroalgal cover is ambiguous. However, the 25 overfished sites surveyed in this study 
were mostly stripped of fishes larger than the mesh-size of nets and fish-traps, including other herbivorous fishes (primarily Scarus species and acanthurids). It could also be argued that in the absence of size data (and hence, biomass), any relationship between fish abundance and macroalgal cover is equivocal. But, again, we know that the fishes at the overfished sites were both very small and relatively few compared to less-fished sites, due to the fishing methods employed at overfished sites. While it is true that one other wide-ranging survey study documented a negative correlation between fish and macroalgal biomass (Newman et al. 2006), no previous study has targeted intensively overfished sites over as wide a region as reported herein (Jamaica, Panama, Martinique, St. Lucia, Puerto Rico and the Dominican Republic in the present study; only Jamaica in Newman et al., 2006). Rather than a gradient in fishing pressure, as in Newman et al. (2006), the present study targeted the presence and absence of intensive fishing by specifically surveying sites that were intensively overfished and relatively protected from fishing.

The present study is not alone in its conclusions, as other survey studies have noted the absence of a correlation between macroalgal cover and herbivorous fish counts (Lirman \& Biber 2000) and MPA status of reef sites (Toth et al. 2014). Furthermore, higher levels of nutrients from the excretion of reef fishes (as total fish biomass) has been shown to correlate with greater macroalgal cover (Burkepile et al. 2013), a conclusion that is supported by the present study. Comparisons of Caribbean reefs with those of the Indo-Pacific have led some to question the top-down control of macroalgae by herbivorous fishes on the former (Roff \& Mumby, 2012). Caribbean reefs suffered the catastrophic loss of the sea urchin Diadema antillarum RA Philippi, 1845 in the early 1980s, and this species may have played a disproportionate role in herbivory (Shulman \& Robertson, 1996) relative to what occurs on Indo-Pacific reefs. In the present study, the abundant macroalgal cover at geographically isolated, lessfished sites in the SE Bahamas or Banco Chinchorro, Mexico, could be attributed to higher nutrient 
250 addition from total fish biomass, to the continued absence of $D$. antillarum, or to differences in

251 macroalgal species and palatability among sites. For example, the unpalatable Microdictyon spp.

252 (Lapointe et al., 2004) and Dictyota spp. (Hay, 1991) were common in our surveys of these sites and 253 are generally avoided by fish grazers. While we did not enumerate $D$. antillarum in this study, it may

254 be that populations of this important herbivore are rebounding faster on overfished reefs where urchin

255 predators have been removed by fish-trapping, along with herbivorous and spongivorous fishes. If true,

256 this may explain the generally lower levels of macroalgae on overfished reefs observed in this study.

257 Despite the limitations of the survey data as discussed above in addressing the relationship between

258 herbivorous fishes and macroalgae on Caribbean reefs, the surprising outcome, combined with the

259 scale of this study, the choice of intensively overfished sites, and very recent reassessments of the

260 impacts of fish herbivores on Caribbean reefs (Adam et al. 2015) argue for its consideration in future,

261 more targeted, survey studies of the impacts of herbivores on reefs.

\section{Conclusions}

Validating our conceptual ecosystem model (Pawlik, 2011), Caribbean reef sponges provide a

rare example of indirect effects at the community level, in which a group of consumer species

(primarily angelfishes and parrotfishes) act upon a diverse community of sponges to alter their relative abundance and thereby change the competitive interactions of the sponge community with reefbuilding corals. In the present study, indirect effects were propagated from human fishing activities, but this role may have been played by higher-level predatory fishes in the past, likely from two trophic levels (requiem sharks - large groupers and snappers), although probably not as effectively as human fish-trapping removes sponge predators. On the other end of the model, palatable sponges compete with corals on overfished reefs, but also appear to compete with macroalgae, as the abundance of the two were inversely correlated. In contrast to this model system, most commonly cited examples of 
273 indirect effects are simple ecosystems with trophic levels often identified as individual species (e.g., 274 orca - sea otter - urchin - kelp; wolf - elk - aspen - songbirds, Wootton, 1994; Hebblewhite et al., 275 2005). Despite the high species-diversity at each level, the clarity of indirect effects observed for the 276 Caribbean reef sponge ecosystem is likely due to the simplicity of the interactions relative to other, 277 particularly terrestrial, ecosystems (Polis et al., 2000): abiotic influences on the system are minimal, 278 top-down effects are dominant, sponge community composition is similar across the entire

\section{Acknowledgments}

We thank collaborators and staff from Aquarius Reef Base, St. Eustatius National Marine Park, Soufrière Marine Management Association (St. Lucia), Smithsonian Tropical Research Institute Bocas station (Panama), CARMABI (Curaçao), Punta Cana Ecological Foundation (Dominican Republic), Discovery Bay Marine Laboratory (Jamaica), Action Adventure Divers (St. Lucia), Scubafun Dive Center (Dominican Republic), Espace Plongée Martinique, Florida Keys National Marine Sanctuary, the governments of the Bahamas, Mexico and the Cayman Islands, and the crew of R/V Walton Smith, who variously facilitated permits and provided valuable logistical and field support. Fieldwork was conducted under Permit FKNMS-2009-126 in the Florida Keys, National Commission on Aquaculture and Fisheries (Comisión Nacional de Acuacultura y Pesca) Permit DAPA/2/06504/110612/1608 in the Yucatan (Mexico), Department of Marine Resources Permit MAF/LIA/22 (Bahamas Islands), and unnumbered permits or research contracts from St. Lucia, the Cayman Islands, and St. Eustatius. 
297

298

299

300

301

302

303

304

305

306

307

308

309

310

311

312

313

314

315

316

317

318

319

320

321

322

323

324

325

326

327

328

\section{References}

Adam TC, Burkepile DE, Ruttenberg BI, Paddack MJ. 2015. Herbivory and the resilience of Caribbean coral reefs: knowledge gaps and implications for management. Marine Ecology Progress Series 520:1-20

Aronson RB, Precht WF, Toscano MA, Koltes KH. 2002. The 1998 bleaching event and its aftermath on a coral reef in Belize. Marine Biology 141:435-447

Burke L, Maidens J. 2004. Reefs at Risk in the Caribbean. Washington DC: World Resources Institute

Burkepile DE, Allgeier JE, Shantz AA, Pritchard CE, Lemoine NP, Bhatti LH, Layman CA. 2013.

Nutrient supply from fishes facilitates macroalgae and suppresses corals in a Caribbean coral reef ecosystem. Scientific Reports 3:1493

Clarke K. 1993. Non-parametric multivariate analyses of changes in community structure. Australian Journal of Ecology 18:117-143

Farber S, Costanza R, Childers DL, Erickson J, Gross K, Grove M, Hopkinson CS, Kahn J, Pincetl S, Troy A, Warren P, Wilson M. 2006. Linking Ecology and Economics for Ecosystem Management. BioScience 56:121

Fox R, Bellwood D. 2007. Quantifying herbivory across a coral reef depth gradient. Marine Ecology Progress Series 339:49-59

Fretwell S. 1987. Food chain dynamics: the central theory of ecology? Oikos 50:291-301

De Goeij JM, van Oevelen D, Vermeij MJA, Osinga R, Middelburg JJ, de Goeij AFPM, Admiraal W. 2013. Surviving in a Marine Desert: The Sponge Loop Retains Resources Within Coral Reefs. Science 342: $108-110$

Hay ME. 1991. Fish-Seaweed Interactions on Coral Reefs: Effects of Herbivorous Fishes and Adaptations of Their Prey. In: Sale P ed. The Ecology of Fishes on Coral Reefs. San Diego, CA: Academic Press, 96-199.

Hebblewhite M, White CA, Nietvelt CG, McKenzie JA, Hurd TE, Fryxell JM, Bayley SE, Paquet PC. 2005. Human activity mediates a trophic cascade caused by wolves. Ecology 86:2135-2144

Hooper DU, Chapin FS, Ewel JJ, Hector A, Inchausti P, Lavorel S, Lawton JH, Lodge DM, Loreau M, Naeem S, Schmid B, Setälä H, Symstad AJ, Vandermeer J, Wardle DA. 2005. Effects of biodiversity on ecosystem functioning: A consensus of current knowledge. Ecological Monographs 75:3-35

Knowlton N, Jackson JBC. 2008. Shifting baselines, local impacts, and global change on coral reefs. PLoS biology 6:e54 
Lapointe B, Barile P, Yentsch C, Littler M, Littler D, Kakuk B. 2004. The relative importance of nutrient enrichment and herbivory on macroalgal communities near Norman's Pond Cay, Exumas Cays, Bahamas: a "natural" enrichment experiment. Journal of Experimental Marine Biology and Ecology 298:275-301

Lirman D, Biber P. 2000. Seasonal dynamics of macroalgal communities of the northern Florida reef tract. Botanica Marina 43:305-314

Loh T-L, Pawlik J. 2012. Friend or foe? No evidence that association with the sponge Mycale laevis provides a benefit to corals of the genus Montastraea. Marine Ecology Progress Series 465:111117

Loh T-L, Pawlik JR. 2014. Chemical defenses and resource trade-offs structure sponge communities on Caribbean coral reefs. Proceedings of the National Academy of Sciences of the United States of America 111:4151-4156

Lokrantz J, Nyström M, Thyresson M, Johansson C. 2008. The non-linear relationship between body size and function in parrotfishes. Coral Reefs 27:967-974

Low-Décarie E. 2014. Rising complexity and falling explanatory power in ecology. Frontiers in Ecology and the Environment 12:412-418

Menge B. 1995. Indirect effects in marine rocky intertidal interaction webs: Patterns and importance. Ecological Monographs 65: 21-74.

Newman MJH, Paredes GA, Sala E, Jackson JBC. 2006. Structure of Caribbean coral reef communities across a large gradient of fish biomass. Ecology Letters 9:1216-27

NOAA. 2014. NOAA lists 20 species as threatened under the Endangered Species Act. http://www.noaanews.noaa.gov/stories2014/20140827_corallisting.html.

Pawlik J, Chanas B, Toonen R, Fenical W. 1995. Defenses of Caribbean sponges against predatory reef fish: I. Chemical deterrency. Marine Ecology Progress Series 127:183-194

Pawlik JR, Steindler L, Henkel TP, Beer S, Ilan M. 2007. Chemical warfare on coral reefs: Sponge metabolites differentially affect coral symbiosis in situ. Limnology and Oceanography 52:907911

Pawlik JR. 2011. The Chemical Ecology of Sponges on Caribbean Reefs: Natural Products Shape Natural Systems. BioScience 61:888-898

Pawlik JR, Loh T-L, McMurray SE, Finelli CM. 2013. Sponge communities on Caribbean coral reefs are structured by factors that are top-down, not bottom-up. PloS One 8:e62573

Pawlik JR, McMurray SE, Erwin P, Zea S. 2015. A review of evidence for food-limitation of sponges on Caribbean reefs. Marine Ecology Progress Series 519:265-283 
Polis GA, Sears AL., Huxel GR, Strong DR, Maron J. 2000. When is a trophic cascade a trophic cascade? Trends in Ecology \& Evolution 15:473-475

Porter JW, Targett NM. 1988. Allelochemical interactions between sponges and corals. The Biological Bulletin 175:230-239

Randall J, Hartman W. 1968. Sponge-feeding fishes of the West Indies. Marine Biology 1:216-225

Roff G, Mumby PJ. 2012. Global disparity in the resilience of coral reefs. Trends in Ecology and Evolution 27:404-13

Strong DR. 1992. Are Trophic Cascades All Wet? Differentiation and Donor-Control in Speciose Ecosystems. Ecology 73:747-754

Sullivan B, Faulkner DJ, Webb L. 1983. Siphonodictidine, a metabolite of the burrowing sponge Siphonodictyon sp. that inhibits coral growth. Science 221:1175-1176

Thacker RW, Becerro MA, Lumbang WA, Paul VJ. 1998. Allelopathic Interactions between Sponges on a Tropical Reef. Ecology 79:1740-1750

Toth LT, van Woesik R, Murdoch TJT, Smith SR, Ogden JC, Precht WF, Aronson RB. 2014. Do notake reserves benefit Florida's corals? 14 years of change and stasis in the Florida Keys National Marine Sanctuary. Coral Reefs 33:565-577

Wilkinson CR, Cheshire AC. 1990. Comparisons of sponge populations across the Barrier Reefs of Australia and Belize : evidence for higher productivity in the Caribbean. Marine Ecology Progress Series 67:285-294

Wootton J. 1994. The nature and consequences of indirect effects in ecological communities. Annual Review of Ecology and Systematics 25:443-466 


\section{Table $\mathbf{1}$ (on next page)}

Percentage of the ten most common sponge species overgrowing reef-building corals on less-fished and overfished reefs, indicating the chemical defense category of each species. 


\begin{tabular}{|lcc|lcc|}
\hline \multicolumn{2}{|c|}{ Less-fished } & \multicolumn{4}{c|}{ Overfished } \\
\hline Species & $\mathbf{\%}$ & Defense & Species & \% & Defense \\
\hline Aplysina cauliformis & 14.29 & $\mathrm{D}$ & Niphates erecta & 9.72 & $\mathrm{P}$ \\
Mycale laevis & 12.44 & $\mathrm{P}$ & Amphimedon compressa & 8.34 & $\mathrm{D}$ \\
Ircinia felix & 6.76 & $\mathrm{D}$ & Aplysina cauliformis & 8.17 & $\mathrm{D}$ \\
Svenzea zeai & 6.45 & $\mathrm{D}$ & Mycale laevis & 8.08 & $\mathrm{P}$ \\
Amphimedon compressa & 5.07 & $\mathrm{D}$ & Chondrilla nucula & 7.66 & $\mathrm{P}$ \\
Agelas citrina & 3.84 & $\mathrm{D}$ & Iotrochota birotulata & 5.42 & $\mathrm{P}$ \\
Xestospongia muta & 3.38 & $\mathrm{P}$ & Xestospongia proxima & 4.91 & $\mathrm{P}$ \\
Aplysina fistularis & 3.07 & $\mathrm{D}$ & Aplysina fulva & 4.82 & $\mathrm{D}$ \\
Aiolochroia crassa & 2.76 & $\mathrm{D}$ & Amphimedon erina & 2.75 & $\mathrm{D}$ \\
Niphates erecta & 2.76 & $\mathrm{P}$ & Haliclona walentinae & 2.58 & $\mathrm{D}$ \\
\hline
\end{tabular}

$\mathrm{D}=$ chemically defended, or $\mathrm{P}=$ palatable (including chemically undefended and variably defended species). Defense category based on previous research (Pawlik et al., 1995; Loh \& Pawlik, 2014). 
Table 2 (on next page)

SIMPER dissimilarity matrix for square-root transformed occurrences of benthic categories between less-fished and overfished sites. 


\begin{tabular}{|c|c|c|c|c|c|c|}
\hline \multicolumn{7}{|c|}{ Average dissimilarity $=32.77$} \\
\hline & Less-fished & Overfished & & & & \\
\hline $\begin{array}{l}\text { Benthic } \\
\text { category }\end{array}$ & $\begin{array}{c}\text { Average } \\
\text { abundance }\end{array}$ & $\begin{array}{c}\text { Average } \\
\text { abundance }\end{array}$ & $\begin{array}{c}\text { Average } \\
\text { dissimilarity }\end{array}$ & $\begin{array}{c}\text { Dissimilarity } \\
\text { SD }\end{array}$ & $\begin{array}{c}\% \% \\
\text { contribution }\end{array}$ & $\begin{array}{c}\text { Cumulative } \\
\%\end{array}$ \\
\hline Macroalgae & 13.56 & 10.02 & 5.34 & 1.41 & 16.29 & 16.29 \\
\hline Turf & 6.85 & 7.02 & 3.94 & 1.44 & 12.03 & 28.32 \\
\hline Sponge & 8.17 & 11.45 & 3.43 & 1.17 & 10.47 & 38.79 \\
\hline Rock & 8.00 & 5.78 & 3.32 & 1.47 & 10.12 & 48.91 \\
\hline Hard coral & 9.84 & 8.99 & 3.03 & 1.42 & 9.24 & 58.15 \\
\hline $\begin{array}{l}\text { Coralline } \\
\text { algae }\end{array}$ & 6.49 & 3.41 & 2.58 & 1.42 & 7.88 & 66.04 \\
\hline Gorgonian & 3.58 & 2.69 & 2.24 & 1.35 & 6.84 & 72.88 \\
\hline Sand & 5.47 & 5.51 & 2.04 & 1.37 & 6.21 & 79.09 \\
\hline Silt & 0.86 & 2.61 & 1.79 & 0.89 & 5.47 & 84.56 \\
\hline Rubble & 2.56 & 3.22 & 1.70 & 1.18 & 5.18 & 89.74 \\
\hline Fire coral & 1.41 & 1.19 & 1.15 & 1.00 & 3.50 & 93.25 \\
\hline
\end{tabular}

$\%$ contribution indicates the contribution to dissimilarity between less-fished and overfished groups. 
1

Overgrowth of corals by sponges.

Brain coral Diploria labyrinthiformis C Linnaeus, 1758 overgrown by the most abundant Caribbean sponges in the chemically defended category (A) Aplysina cauliformis, and in the palatable category (B) Mycale laevis. (Hogsty Reef, Bahamas; Bocas del Toro, Panama, respectively). 
PeerJ Reviewing Manuscript

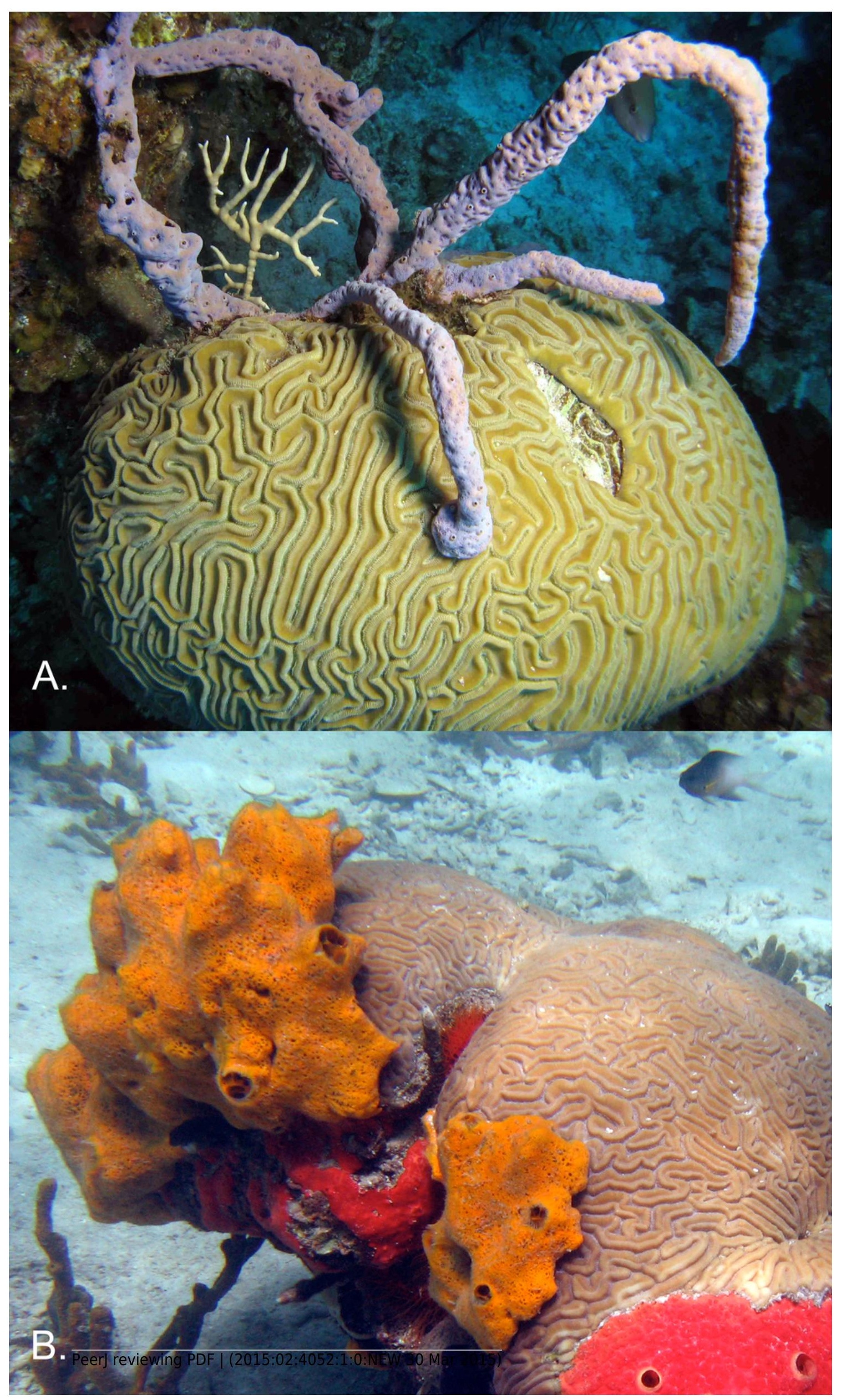


2

Coral-sponge interactions for reef sites that were less-fished $(n=44)$ and overfished $(n=25)$.

Mean percentage of coral colonies surveyed that were growing adjacent to, or overgrown by, sponges. Error bars denote standard errors.

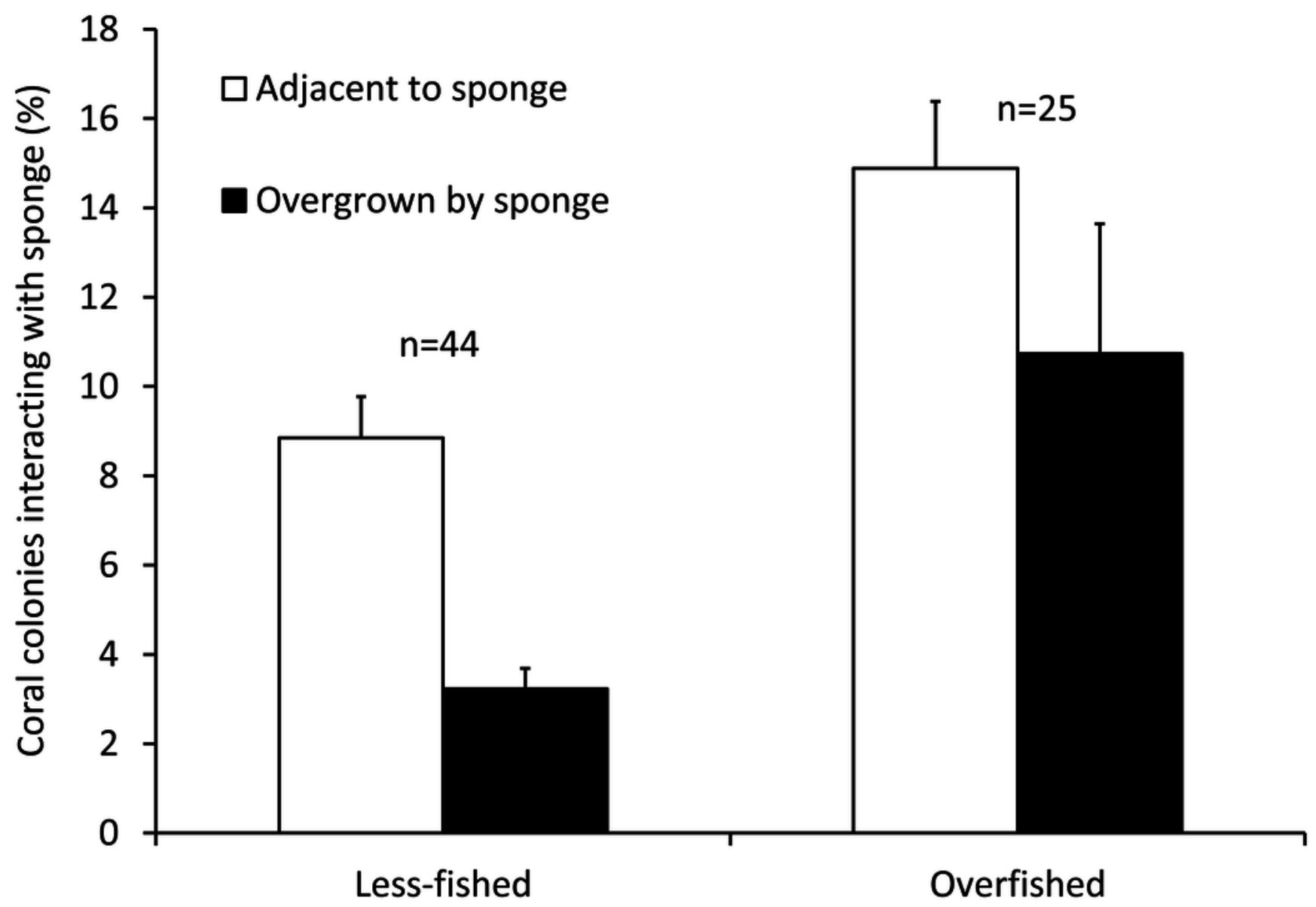


Figure 3 (on next page)

nMDS plot of survey sites relating the percentage of coral colonies that had no interaction with sponges, growing adjacent to sponges and overgrown by sponges at each site.

[p] Sites labeled black are

less-fished, and sites labeled red are overfished. Factors labeled in blue (Overgrown, Adjacent, No interaction). Prefixes of site names denote the following locations: B, Bahamas; C, Cayman Islands; D, Dominican Republic; E, St. Eustatius; F, Key Largo, FL; J, Jamaica; M, Martinique; O, Bonaire; P, Bocas del Toro, Panama; R, Puerto Rico; S, St. Lucia; U, Curaçao; X, Mexico. [p] 


\section{stress $=0.02$}

命

P4

Pिvergिpown

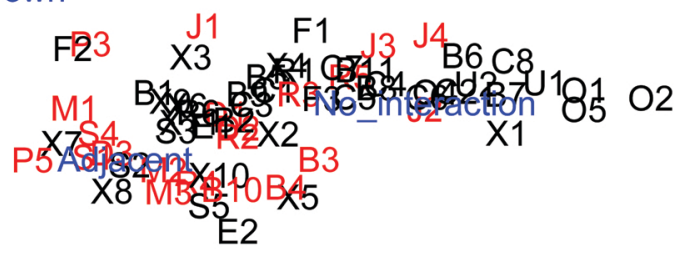

$\mathrm{O} 3$

$\begin{aligned} & 0 \\ & 0 \\ & 1 \\ & 0 \\ & 0 \\ & 0 \\ & 1 \\ & 0 \\ & 0 \\ & 0\end{aligned}-$

0.0

0.5 
4

Linear regression plots of benthic cover vs. SI

(A) Palatable sponge cover, (B) percentage of corals overgrown by sponges and (C)

macroalgal cover vs. SI. Cover is defined as the number of occurrences in 625 benthic survey points at each site. 

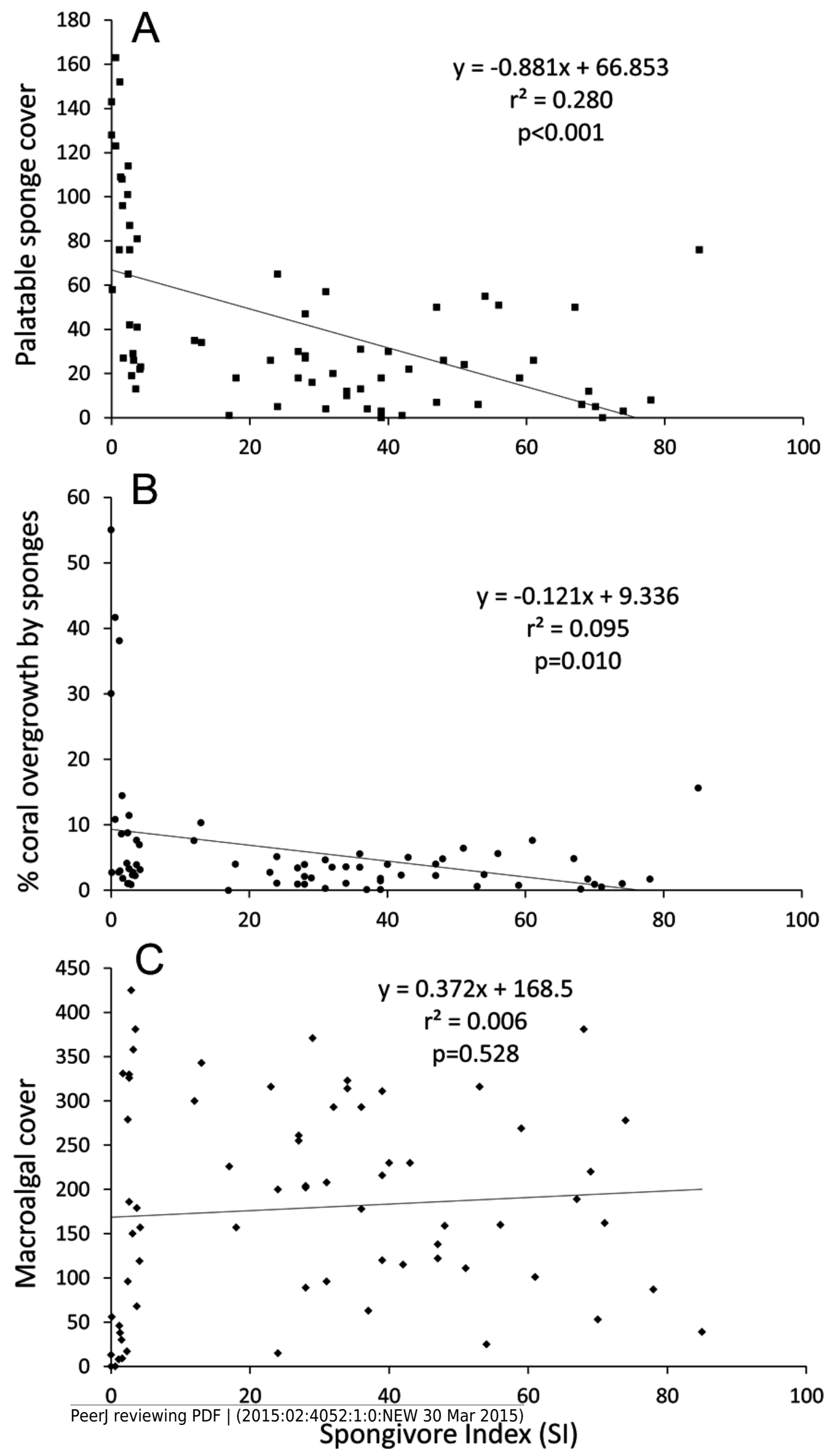